\title{
The impact of a 2-year Etanercept administration on growth of patients with juvenile idiopathic arthritis
}

\author{
M Trachana ${ }^{*}$, P Triantafyllou, A Vraka, E Kaitalidou, P Pratsidou-Gertsi \\ From 18th Pediatric Rheumatology European Society (PReS) Congress \\ Bruges, Belgium. 14-18 September 2011
}

\section{Background}

Published data from various regions evidenced that the administration of Etanercept (ET) restored auxological retardation attributed to the process of the chronic joint inflammation.

\section{Aim}

To assess the impact of ET on growth pattern in Greek JIA patients who had a resistant poly- or an oligoarthritis. Methods: Data of 24 JIA patients (F:M 19:5, 20/24 with a polyarthritis) who had received ET at a median age of 6.7 yrs (1.9-14.5 yrs) escorted by their auxological parameters were collected. Standard Deviation Scores for Height (HSDS) and Body Mass Index (BMISDS) were calculated according to sex- and age- matched percentiles of the healthy Greek population, 2 and 1 yrs pre-ET treatment, and 1 and 2 yrs thereafter. Growth velocity was defined as the change in Height SDS $(\triangle \mathrm{HSDS})$ and in BMI ( $\triangle \mathrm{BMISDS})$ and compared to the time of ET initiation (baseline).

\section{Results}

At baseline 16/24 pts had a growth retardation (median $\triangle$ HSDS -0.56); $11 / 16$ showed a significant increase $1 \mathrm{yr}$ post-treatment $(\Delta \mathrm{HSDS}+0.29, \mathrm{p}<0.001)$ which did not further increase (2nd yr: $\triangle$ HSDS +0.15). Similarly, at baseline, BMI was retarded in 14/24 pts (median $\triangle$ BMISDS-0.6); in 10/14, BMI increased 1 and $2 \mathrm{yrs}$ post-ET $(\triangle \mathrm{BMISDS}+0.31,+0.12$ respectively, $\mathrm{p}<0.001)$ and remained stable thereafter. Growth and BMI improvements were not associated either with age of ET

\footnotetext{
* Correspondence: mtrachan@auth.gr

$1^{\text {st }}$ Department of Pediatrics, Aristotle University, Ippokration General Hospital, Thessaloniki, Greece
}

initiation, or gender, or presence of ANA, or disease duration, or JIA course or MDVAS.

\section{Conclusion}

ET treatment can restore the linear growth and BMI of JIA patients irrespectively of their demographic or clinical profile.

Published: 14 September 2011

doi:10.1186/1546-0096-9-S1-P149

Cite this article as: Trachana et al:: The impact of a 2-year Etanercept administration on growth of patients with juvenile idiopathic arthritis. Pediatric Rheumatology 2011 9(Suppl 1):P149.
Submit your next manuscript to BioMed Central and take full advantage of:

- Convenient online submission

- Thorough peer review

- No space constraints or color figure charges

- Immediate publication on acceptance

- Inclusion in PubMed, CAS, Scopus and Google Scholar

- Research which is freely available for redistribution

\section{( Biomed Central}

\section{Biomed Central}

